\title{
Belgeo
}

Revue belge de géographie

$1-2 \mid 2005$

Human mobility in a globalising world

\section{Economic development and international migration in the Sangro Valley, Abruzzo - Italy}

Développement économique et migrations internationales dans la Vallée du

Sangro (région des Abruzzes, Italie)

\section{Barbara Staniscia}

\section{(2) OpenEdition}

Journals

Electronic version

URL: http://journals.openedition.org/belgeo/12500

DOI: $10.4000 /$ belgeo. 12500

ISSN: 2294-9135

Publisher:

National Committee of Geography of Belgium, Société Royale Belge de Géographie

Printed version

Date of publication: 30 June 2005

Number of pages: 199-214

ISSN: 1377-2368

\section{Electronic reference}

Barbara Staniscia, "Economic development and international migration in the Sangro Valley, Abruzzo

- Italy", Belgeo [Online], 1-2 | 2005, Online since 27 October 2013, connection on 05 February 2021.

URL: http://journals.openedition.org/belgeo/12500 ; DOI: https://doi.org/10.4000/belgeo.12500

This text was automatically generated on 5 February 2021.

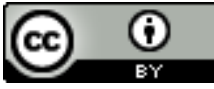

Belgeo est mis à disposition selon les termes de la licence Creative Commons Attribution 4.0 International. 


\section{Economic development and international migration in the Sangro Valley, Abruzzo - Italy}

Développement économique et migrations internationales dans la Vallée du Sangro (région des Abruzzes, Italie)

\section{Barbara Staniscia}

\section{AUTHOR'S NOTE}

Contribution to the Italian PRIN 2002 Research Programme on "Tourism and development. Local peculiarities and territorial competitivity".

The author would like to thank Mr. G. Di Corinto, Mr. R. Di Fonzo and Mr. A. Staniscia, who kindly granted the opportunity to interview them; Mr. A. Amorosi, Mr. G. Basterebbe and Mr. A. Campli, who kindly provided valuable data and information.

\section{The idea and the model}

1 The economist Becattini, when referring to Italy, states "there are several ideal types which can express the "boot", like the masks in the comedy of art. This diversity of the Italian character in comparison to that of other populations, and the current ample range of regional characteristics, is (according to me) our main disadvantage and, at the same time, our secret weapon" (Becattini, 1995-96).

2 It is on this assumption - and on this strong conviction - that this paper is based. That is, that the Italian situation cannot be understood if treated like an undifferentiated unique example. That it cannot be decoded, as a whole, if, first, each individual situation, each single piece of the "mosaic", is not interpreted. And such a conviction is valid for all the manifestations of human actions. 


$$
\begin{aligned}
& \text { is characterised by an economy that was mostly } \\
& \text { medium enterprises (SMEs) and local handicraft. }
\end{aligned}
$$

9 The active population in the agriculture sector represented $62 \%$ of the total active population in the area in the year 1951, but the percentage dropped to $38 \%$ in the year 1971. The profitability of agricultural activity was very differentiated. It was fair in the valley and along the coast, where the areas were characterised by intensive and specialized cultivations, but it was very low on the high hills and mountains, where the areas were characterised by extensive agriculture with strong pathologies. The main problems in the sector were the high fragmentation of the land property (the average dimension of farms was 3.5-4.0 hectares) and the lack of associative and cooperative forms that could compensate for this deficiency. 
Figure 1. Evolution of the Sangro Valley economic system.

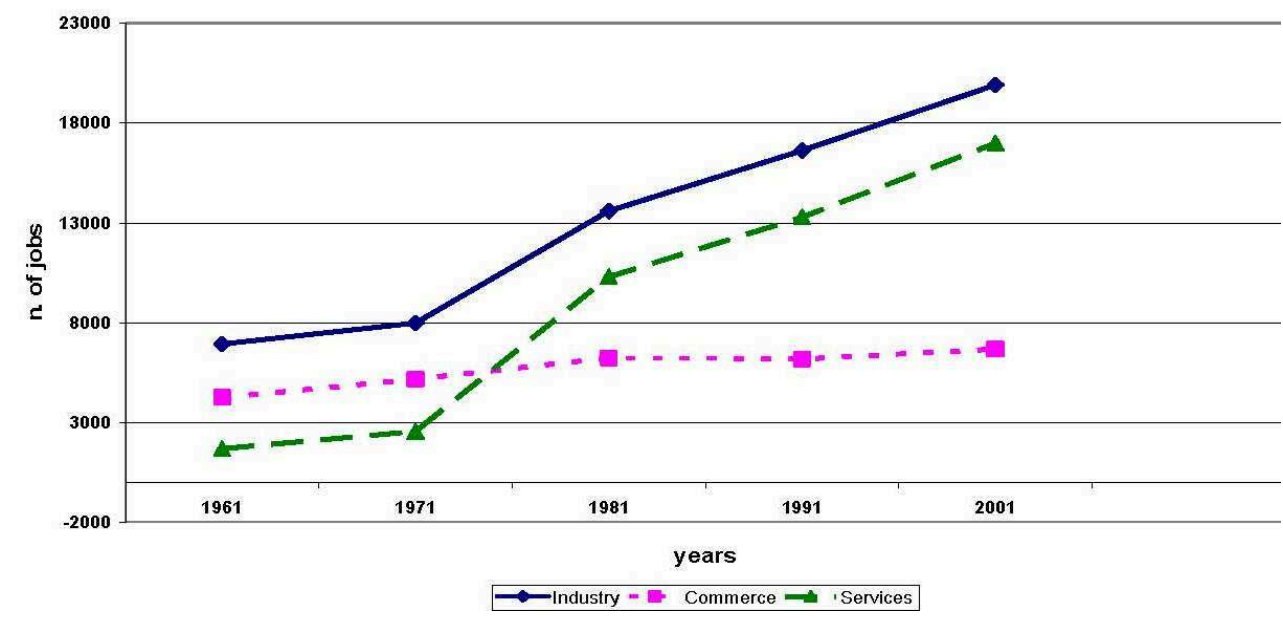

Source: Istat (various years, a); author's own computation. industrial evidence of secular tradition, especially in the mountain areas. The pasta, metal working and wool industries are just a few examples. These were activities which were established along the roads crossed by the Bourbon armies during previous centuries, conceived for the benefit of these armies. They mostly consisted in artisan enterprises of local interest which, in the year 1971, occupied only ${ }^{4} \%$ of the resident population. The average dimensions of these enterprises were very small, around three employees per local unit. The economic sectors represented were those with low startup costs, which required neither a high technological level nor special managerial skills. These included the food, textile, clothing, footwear, leather, wood and furniture sectors (Clementino, 1995). These characteristics, which, certainly not alone, had contributed to the success of the SMEs in the industrial districts of Central and NorthEastern Italy, played a part, indeed, in the industrial crisis in this area. This industry, which was small, traditional, concentrated and non-specialized, experienced a slump during the Sixties.

11 The second phase, which took place between the beginning of the Seventies and the end of the Eighties, begins by finding a solution to the local agriculture and industrial crisis. This period is characterised by the introduction of large enterprises, in particular within the mechanical sector, and by the creation of a system of SMEs working as sub-suppliers of the large enterprises. This takes place in a top-down logic, which includes:

- Incentive policies to encourage the delocation of industrial production from Northern Italy to Southern Italy implemented by the national government. This relates to the so-called "Intervento Straordinario" (Extraordinary Intervention) which provided funds with low interest rates, capital contributions, tax incentives and a reduction in social costs for investments made in Southern Italy.

The Intervento Straordinario was a plan of intervention by the Italian government for the development of the Mezzogiorno (Southern Italy). Its starting point can be fixed at the beginning of the Fifties, more specifically with the Law 646/1950. The aim of this plan was, first, to realize a considerable number of extraordinary public infrastructures in the Southern regions; then, to favour the industrialisation process that in those regions had not 
taken place yet. The final objective was to overcome the traditional dualism that had always characterised the history of Italy (De Rosa, 1997). The most important body of this intervention was the so called "Cassa per il Mezzogiorno" (Fund for the Mezzogiorno), later transformed into "Agenzia per la promozione dello sviluppo del Mezzogiorno" (Agency for the promotion of the development of the Mezzogiorno), the function of which was to implement a policy of development, in particular through the allocation of the special funds previewed for that purpose. The Intervento Straordinario ends, definitely, at the beginning of the Nineties, in particular with the Law 488/1992 and the Legislative Decree 96/1993, which decree, among the others, the cessation of the Intervento Straordinario and the suppression of the "Agenzia per la promozione dello sviluppo del Mezzogiorno". Those laws cancel the policy of extraordinary intervention and insert the development of Southern Italy in the ordinary actions to take in order to develop all the depressed areas of the national territory. This new idea is also a consequence of the policy of regional reequilibrium promoted by the EU (Barbagallo and Bruno, 1997).

The most relevant effects of the Intervento Straordinario in the Sangro Valley, was the creation of areas for the industrial development and the attraction of exogenous investments.

Figure 2. Spatial distribution of the economic activities in the Sangro Valley. 1961-2001.
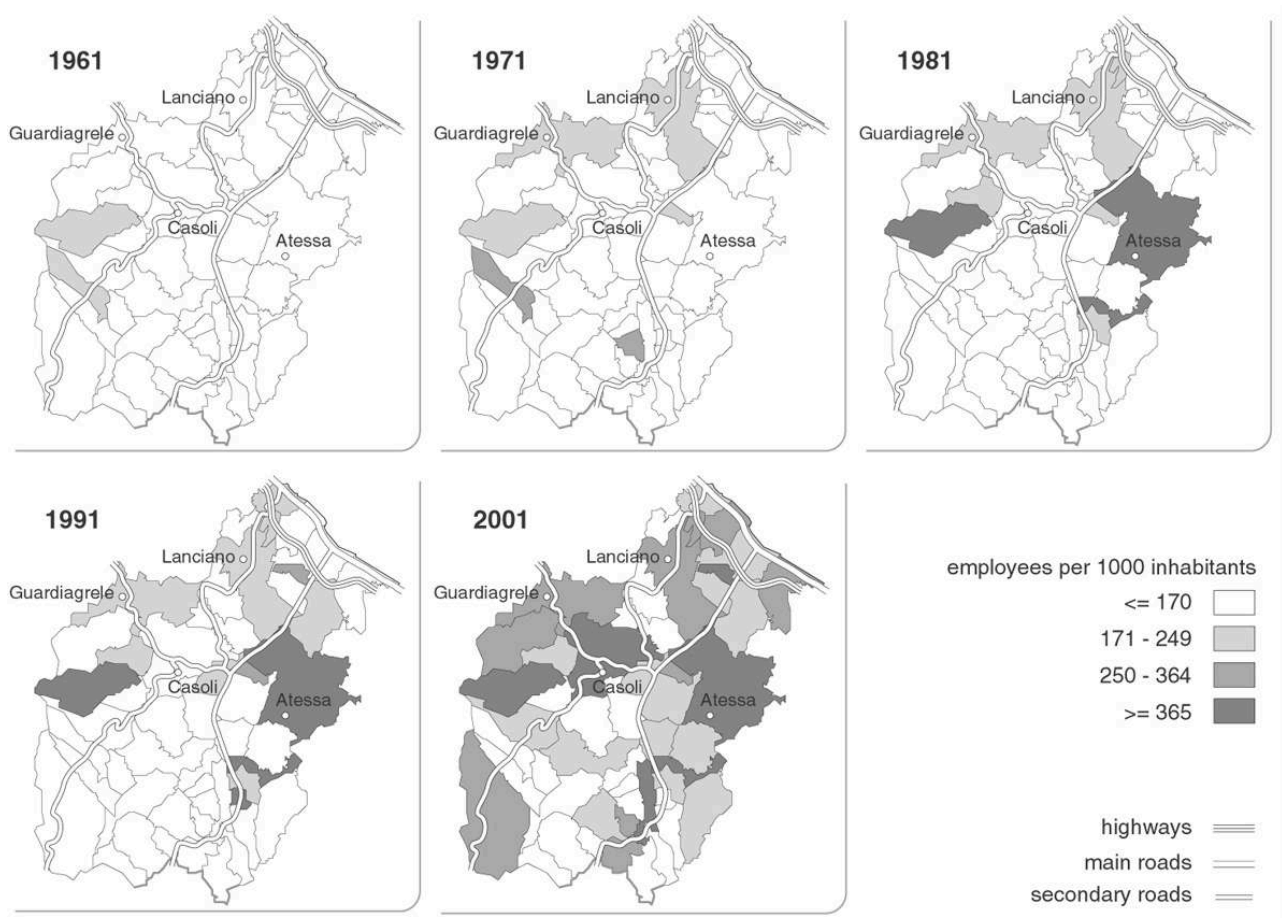

Source: Istat (various years, a); author's own computation

- Delocation options, put into effect by large industrial groups (in the case of the Sangro Valley, especially by the Fiat group), which were the consequence of diseconomies and governability problems associated with the traditional large enterprises located in congested metropolitan areas in social crisis, the effect of the progressive depletion in the workforce in those areas, the development of interesting workforce basins in the South, the take-off of the industrial areas in the Southern regions and the progressive reduction in negative location differentials (R\&P, 1981).

The social conflicts in the large cities of Northern Italy, during the Sixties and the Seventies, 
were due to two major facts: on the one hand to the negative conditions of work in the firms, on the other hand to the unsustainable conditions of life in the cities. The workers in the factories had to suffer long and hard hours of working, high instability of the job, very low safety precautions and inadequate salaries. Outside the workplace, the workers had to experience very difficult conditions of life in terms of housing, social services, school and transport. All that situation was particularly heavy for the Southern immigrants who, "far from being the grateful 'guests of the city' as La Stampa would have liked, were highly critical of a society which had forced them to migrate and which gave them so little (...). The Piedmontese have never had the anger which these uprooted southerners have got" (Ginsborg, 1990).

- Local policies to attract external investments put into effect by local actors, through the construction of infrastructures and the offer of advantageous conditions for the establishment of large enterprises. In 1970, the "Consortium for the development of the Sangro-Aventino industrial area" was constituted. It built all the infrastructures in the industrial areas. Actors in the processes of attraction of external investments were the local authorities, in particular the municipalities; they conducted the negotiations with the big industrial groups. These processes were inspired by Perroux's "pôles de croissance" development idea.

12 The result of the joint action of the three factors listed above was the creation of important industrial firms, amongst which the Piaggio (1974), Honda (1975) and FiatPeugeot-Citroen (1978) groups.

The overall impact of the external enterprises on employment was remarkable. Almost $70 \%$ of the 11,000 employees working in the manufacturing industry in the area in 1991 were employed in the typical non-local enterprise sectors (non metalliferous minerals, means of transport, electronics, electro-technology, chemistry, rubber, plastic). The automobile sector alone covered almost $40 \%$ of the entire area's manufacturing employment. The number of jobs in the industry doubled from 1971 to 1991, increasing from 7,974 to 16,625; although lower, an increase was also registered in the number of jobs in commerce, rising from 5,166 in 1971 to 6,177 in 1991. Finally, there was an explosion in the number of jobs in the services sector, which increased from 2,549 in 1971 to 13,285 in 1991.

14 A development model of this kind, in spite of its tremendous success, had its down side. Indeed, such a massive presence of non-local entrepreneurship was, at the same time, also an element of weakness. This is because the entire development model of the Sangro Valley depended on decisions that were made elsewhere, in the directional centres of large national and international groups. This fact exposed the area to the risk of a reduction in industrial employment in the case of a crisis, and also took the control of the development process out of the hands of local governments and communities.

The third phase, which was initiated at the beginning of the Nineties, is characterised by the stabilization of large enterprises, the arrival of new multinationals, the reinforcement of the SME system in the industrial sector and, also, the strengthening of the tertiary sector. This phase is also characterised by the end of the "Intervento Straordinario" and by the termination of aid provided by EU regional policies for the marginal areas (former Objective 1), because the Sangro Valley was no longer part of these areas. Therefore, new instruments for local development were created, in a bottom-up logic which was characterised by the self-determination and self-regulation 
of the territory through policies that pass as partnerships and governance. A good example of this new logic is the institution, during the second half of the Nineties, of a Normative Industrial District (Carboni, 1996) and of a Territorial Employment Pact (Staniscia, 2002; Staniscia, 2003). In the mountainous part of the area, at the beginning of the Nineties, a natural park of national relevance (Parco Nazionale della Majella Majella National Park) was instituted, which has a strong influence on the territory's human and economic development model, even if its main objective is the preservation of the natural environment.

During the Nineties, the local economy continues to grow: in the year 2001, the number of jobs in industry reaches 19,908, in commerce, 6,680, and in the services sector, 16,987 . The large enterprises continue to produce without reducing jobs and, in some cases, even creating new employment. SMEs mostly operate as sub-suppliers of large enterprises but in the logic of a diversification of purchasers. The area, still linked to a "fordist" model of production, is therefore experimenting alternative paths of development.

During the Nineties the arrival of foreign capital in the area continues. In the year 2001, firms with non-Italian capital or only partly Italian capital, are the largest in the area. The number of jobs directly created by these enterprises is around 8,000 , i.e. $40 \%$ of the total number of jobs in industry in the entire area (CRESA, 2001). To this figure, the number of jobs created by SME sub-suppliers, must also be added.

Table 1. The main phases of the development in the Sangro Valley.

\begin{tabular}{|l|l|l|}
\hline Phases & Years & $\begin{array}{l}\text { Main characteristics of the local } \\
\text { economy }\end{array}$ \\
\hline 1st & $1950-1970$ & $\begin{array}{l}\text { agriculture, endogenous system of } \\
\text { SME, handicraft }\end{array}$ \\
\hline 2nd & $1970-1990$ & $\begin{array}{l}\text { exogenous large enterprises, SME } \\
\text { sub-suppliers, top-down } \\
\text { development }\end{array}$ \\
\hline 3rd & $\begin{array}{l}\text { stabilization of the presence of } \\
\text { large firms and SME, new } \\
\text { multinationals, reinforcement of the } \\
\text { tertiary sector, bottom-up } \\
\text { development }\end{array}$ \\
\hline
\end{tabular}

Source: author's own elaboration

\section{Migratory paths}

Following the scheme traced for the development trajectories, it is possible to divide the migratory paths into three different phases ${ }^{(4)}$.

The migratory behaviour which characterises the Sangro Valley in the first phase (during the Fifties and Sixties, until the beginning of the Seventies) is very similar to that characterising the Abruzzo region and the entire Italian Mezzogiorno ${ }^{5}$. The agriculture caused masses of people to leave the countryside and to swarm to the big urban agglomerates of Central-Northern Italy and abroad (Montanari and Staniscia, 2003; Baldi and Cagiano de Azevedo, 1999; Sonnino, 1995).

The transoceanic destinations were represented by Argentina, Canada, the United States and Australia; the main destinations in Europe were Switzerland, Germany, 
Belgium and France. These countries made agreements with the national government in order to encourage migratory flows.

The population in the area drastically declined from 1951 to 1971, passing from 160,764 inhabitants to 125,857 , registering a decrease of $21.7 \%$. The decrease was exclusively due to the negative migratory balance, because the natural balance had always been positive during the period. During the decade 1961-1971, the total migratory balance (internal and external) exceeded $-26,000$ units. To this negative figure, a large group of people who, even maintaining their residence in the area, was, de facto, in a different municipality in Italy or abroad, must be added. Indeed, if in the year 1951 only $2 \%$ of the population resident in the area was absent because abroad, in the year 1961 this quota reached $6.7 \%$ with peaks rising to $15 \%$ in some mountain municipalities. The situation changed from the beginning of the Seventies.

There were two main phenomena that caused the inversion in the trend:

i. the economic crisis which struck the western world brought back many Italian workers who had emigrated previously and discouraged newcomers;

ii. the national and local policies attracting large enterprises favoured the return of emigrants with the creation of new job opportunities.

Already at the time of the 1971 Census, the percentage of residents in the area temporarily absent because abroad, was nearing the level seen before the crisis: 3.5\%. From 1972, the migratory balance became positive, even though it fluctuated during the decade.

The role played by the policies of attraction in obtaining external investments was quite remarkable. We cite the example of SEVEL (Fiat-Peugeot-Citroen group). At the moment of its institution, the local authorities negotiated very severe criteria of recruitment with the company. One of them was represented by the depopulation index: given a possible basin of manpower (based on the distance between the place of residence and the workplace), the firm engaged itself to hire as more employees from a certain municipality as more were the emigrants from that municipality.

During the Seventies, therefore, the large industrial enterprises were able to recuperate local citizens who had emigrated during former decades. However, the phenomenon of new foreign arrivals was not yet being registered, in a strict sense.

In fact, if we look at the composition of foreign presence in the Sangro Valley at the 1981 Census, we can observe the following:

- a small presence of foreign residents: 550 units, representing $0.4 \%$ of the total resident population;

- a very high percentage (71.4\%) of non-active population among foreigners, amongst which: students (26.4\%), retired people (15.3\%), housewives (14.7\%), unemployed people looking for their first job (3.2\%), other non-active people (11.8\%);

- a very high concentration of active foreign population in the group of manual workers. 
Figure 3. International Migration in the Sangro Valley: 1972-2000.

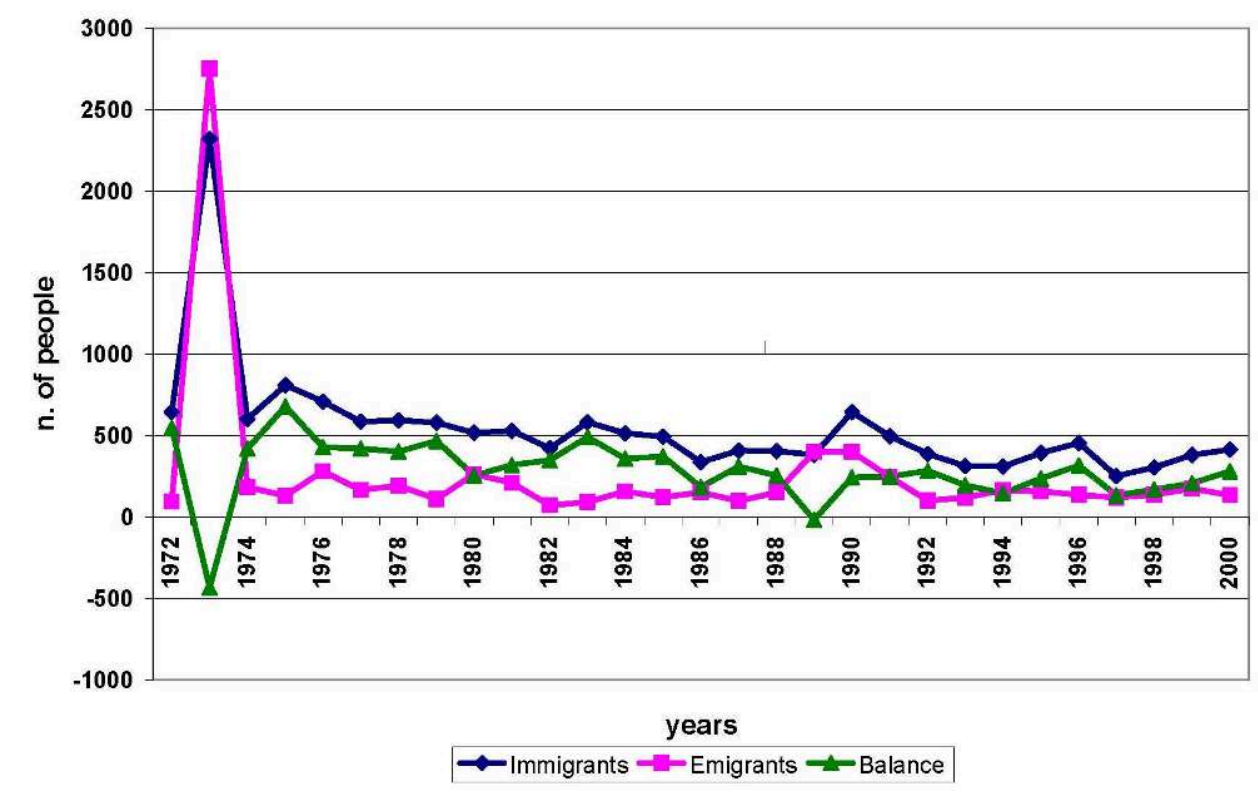

Source: Istat (various years, c); author's own computation

This context seems to confirm the hypothesis of returning migration. Foreign citizens in 1981 seem to be elderly people who had emigrated and who had then returned to benefit from their retirement in Italy, their wives, and young couples who had emigrated and who had then returned with their children who had been born abroad.

The only exception to this rule seems to be represented by a small group of Japanese who arrived at the end of the Seventies following the institution of the Honda factory. This occurred during a time when Honda had to convert its production from merely assembling pieces of motorcycles to completely building motorcycles. The Japanese Honda managers, technicians and manual workers came to the area in order to pass on their know-how to the Italians involved in production. This is a very good example of human and technological direct transfer that followed the simple transfer of capital.

The spatial distribution of the foreign population in the area supports this hypothesis. The incidence of foreigners on the total population is particularly high in some mountain municipalities (precisely those which had experimented the highest rates of depopulation) and in some municipalities in the plains where the industrial firms were located (Fig 4). The concentration in this latter group of municipalities is particularly evident if we take into account the spatial distribution of the foreign population in the area (Fig. 5). 
Figure 4. Presence of the foreign residents in the Sangro Valley in the years 1981-1991-1993-2000.

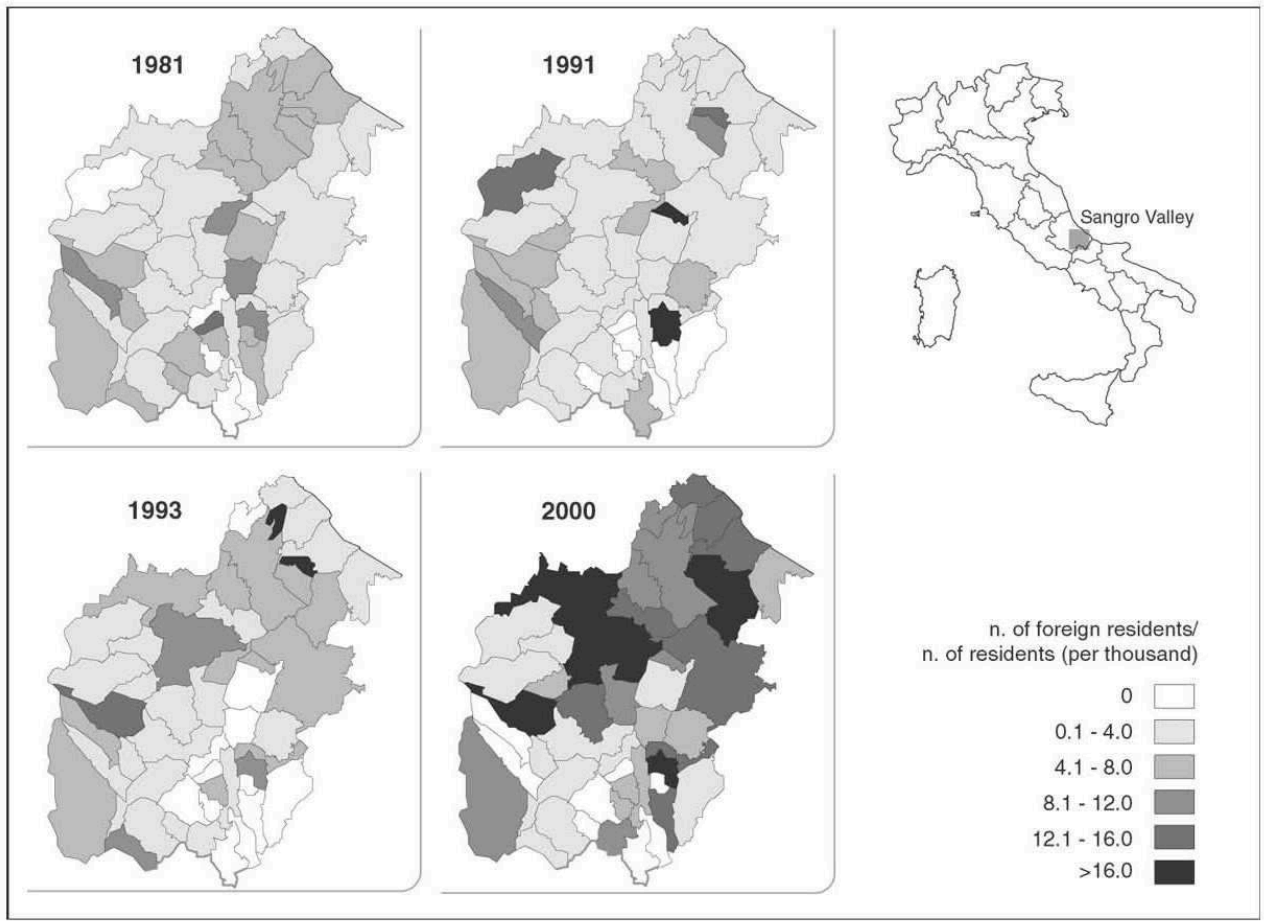

Source: Istat (various years, b); author's own computation; Istat (various years, d); author's own computation

Figure 5. Spatial distribution of the foreign residents in the Sangro Valley in the years 1981-1991-1993-2000.

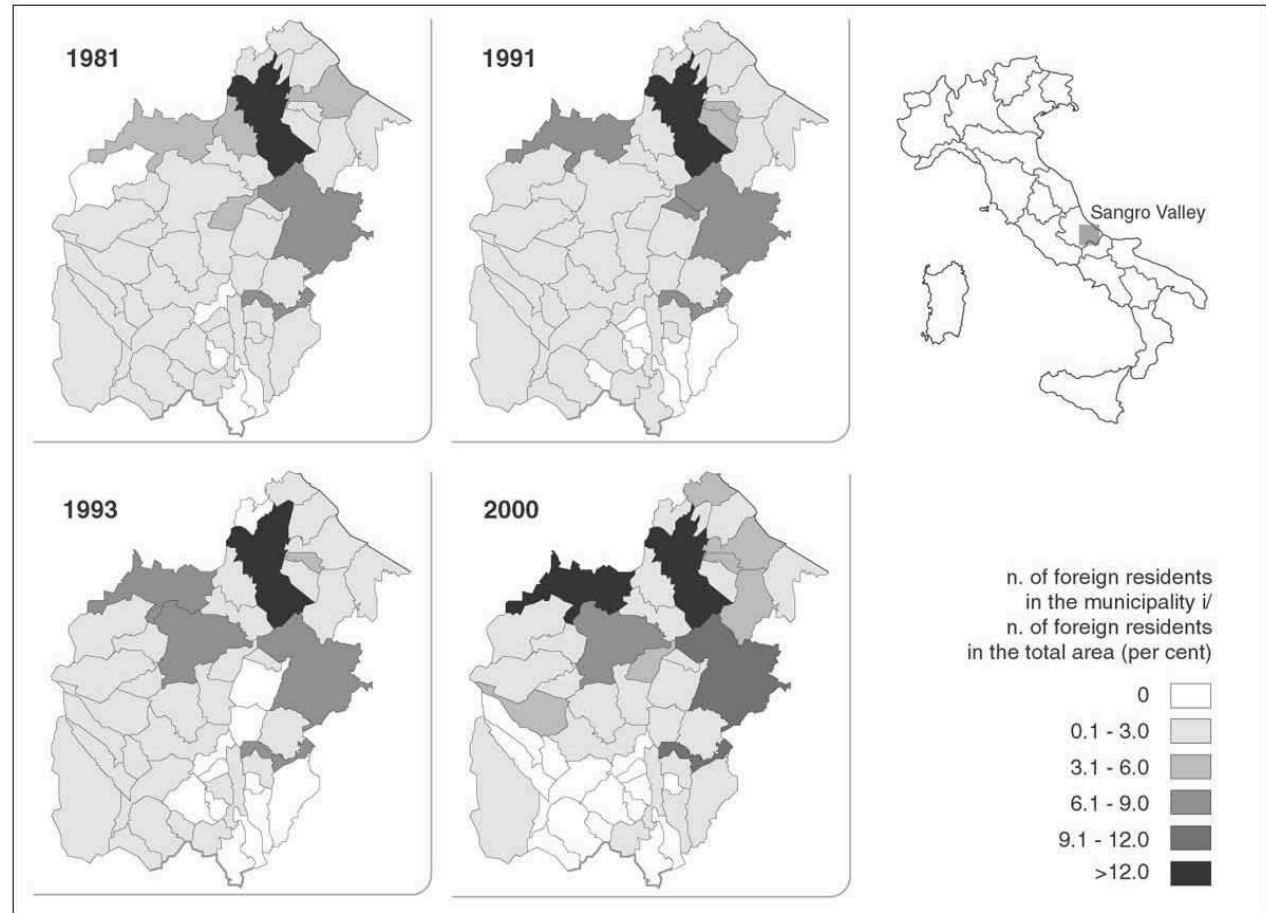

Source: Istat (various years, b); author's own computation; Istat (various years, d); author's own computation 
The Eighties registered an initial change in the migratory processes that took place in the area. The creation of new jobs in large enterprises was slowing down; new SMEs were developing, more willing to employ seasonal and irregular workers. Foreign presence begins to modify its own composition.

At the 1991 Census, the incidence of returning migration continued to be high. Among the 544 foreign citizens who were residents in the area, $23.7 \%$ were represented by citizens coming from Latin America, particularly from Argentina, and $19.3 \%$ was constituted by citizens coming from EFTA countries, particularly from Switzerland, traditional countries of long-standing, local emigration.

New presences started appearing: citizens from Africa (13.7\%), particularly from Northern Africa, and from Eastern Europe (7.9\%).

Density and spatial distribution remain substantially unvaried in comparison to the 1981 (Fig. 4 \& 5).

The true novelty in migratory paths involving the Sangro Valley concerns the Nineties.

During the period 1993-2000, foreign presence in the area increases by a total of 774 units $(+103 \%)$. The highest increases are registered in the largest and economically most dynamic municipalities and in the coastal municipalities, which are also those with the highest rates in the increase of total population. Increases are also registered in some mountain municipalities, which are not necessarily dynamic in an economic sense, but which are characterised by open and hospitable local communities and administrated by local authorities that encourage "repopulation" through policies to attract foreign citizens.

The Eastern-Europeans (+359\% between 1993 and 2000) and the North-Africans $(+148 \%$ in the same period) are the groups that present the highest growth rates. At the same time, a strong decrease is registered in the arrival of citizens from the EU (-2\%), Latin America (-11\%), and North America (-56\%), i.e., those who had registered the highest presence until the beginning of the decade.

8 The calculation of presence (Fig. 4) and spatial distribution (Fig. 5) for the Nineties can also be usefully used.

Between 1993 and 2000, the incidence of foreign citizens grows in a group of piedmont and mountain municipalities on the left bank of the Sangro River and in a small group of hilly municipalities. This fact can be explained by two factors: in the case of the mountain municipalities, through policies of attraction and hospitality put into effect by the local communities and public authorities; in the case of the small hilly municipalities, the reason can be attributed to new residential opportunities in new urban settlements not far from the industrial sites. In the municipalities with a very dynamic economy, the number of foreigners is still high. 
Figure $6 a-6 b$. Provenance of the foreign residents in the Sangro Valley in the years 1993 and 2000.
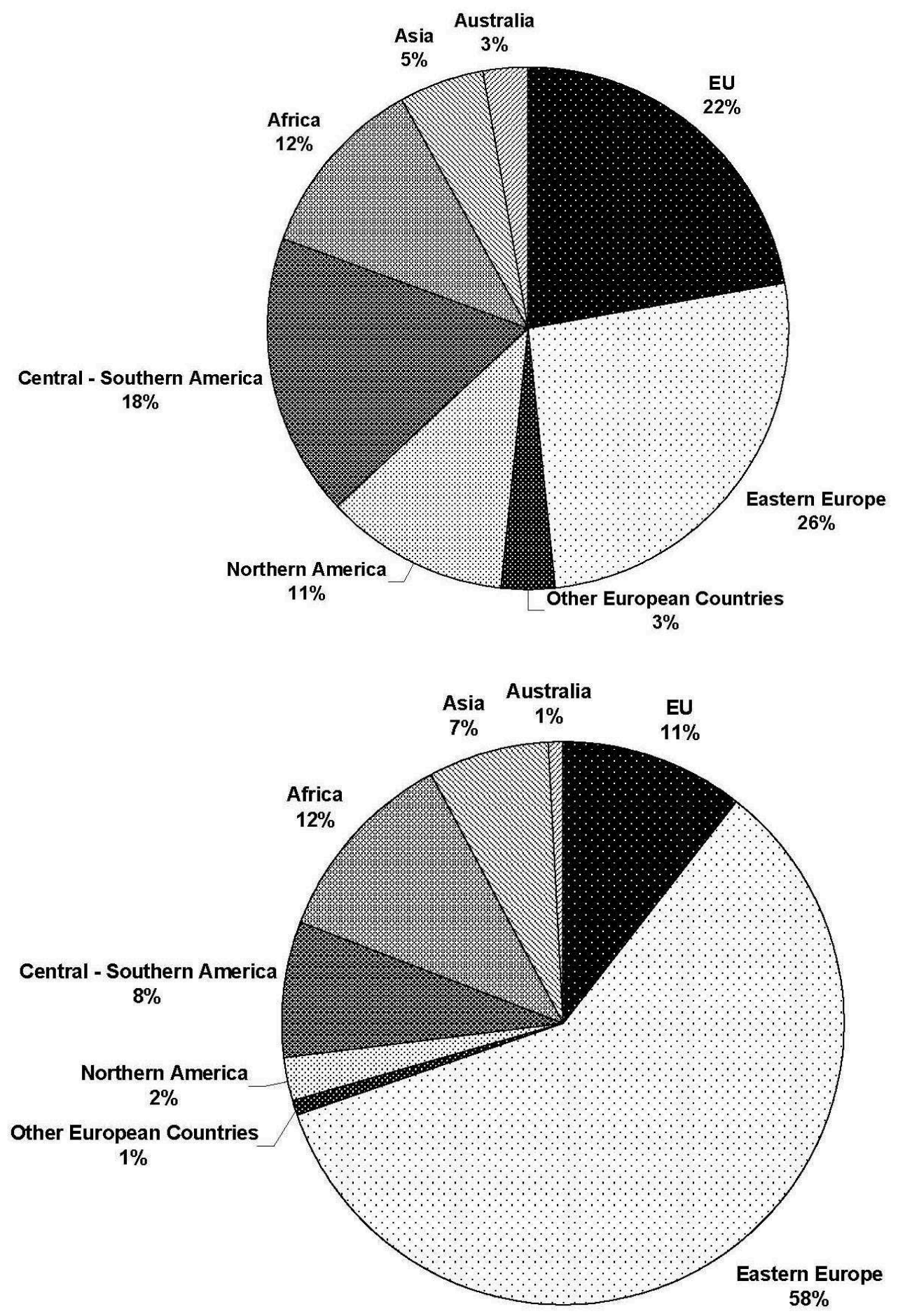

Source: Istat (various years, d); author's own computation The ten largest communities in the year 2000 have been studied, representing $72.2 \%$ of the total foreign presence in the Sangro Valley.

The location quotient (Isard, 1960) has been taken into account in order to analyse the distribution of these communities throughout the area (Fig. 7). The quotient represents 
the ratio between the community proportion in the municipality and the community proportion in the entire area.

Figure 7. Location Quotient for the ten largest foreign communities in the Sangro Valley in the year 2000.

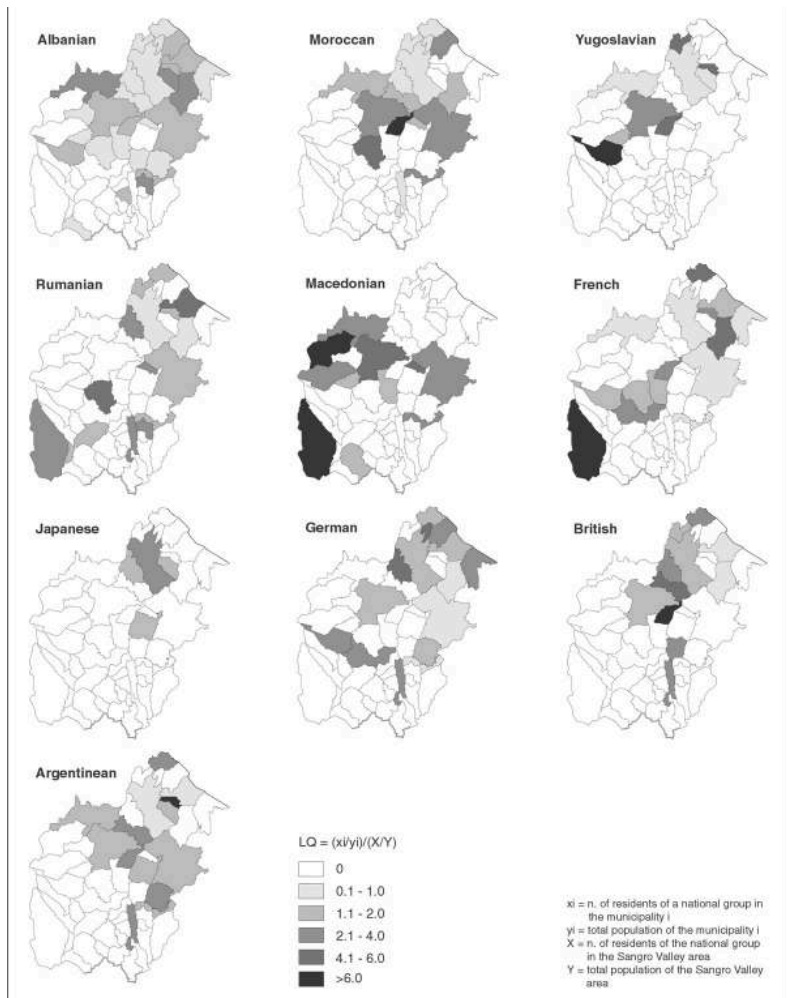

Source: Istat (various years, d); author's own computation

Among the Eastern-European communities, the Albanian one is the most widely represented. From 1993 to 2000, it registered a remarkable increase, rising from 64 to 587 units, from $8.6 \%$ to $38.7 \%$ of the foreigners in the area. Its members are spread all over the coastal, hilly and piedmont territory and they prefer the most populated centres. The other three Eastern-European communities represent a much lower quota in comparison to the Albanians: Yugoslavians, 5.0\%; Romanians, 4.3\% and Macedonians, 3.7\%. Although they prefer the large urban agglomerates, these communities, particularly the Macedonians, are also spread out in the mountain municipalities. The trend shown by Eastern-European communities must be attributed to the activities in which they are involved: traditional jobs as non-specialized workers in the construction industry and in the agricultural sector (male component), as assistants to old people and as housekeepers (female component). To these main activities, other ones have to be added: jobs as shepherds, in particular for the Macedonian group; jobs as technicians in local micro-enterprises, especially for the Romanian group. 
(the French community represents $2.76 \%$ of total foreigners, the German and British communities $2.37 \%$, and the Japanese community $2.57 \%$ ), it is important because it is the expression of the development model of the area represented by the presence of multinational firms.

In the case of these European Union citizens, in fact, to the traditional group of elderly people who are returning migrants, a new group has to be added: the youngest one, composed by highly qualified manpower working for the multinational companies.

Let us take the example of Honeywell, the United States giant. Two interesting phenomena can be observed in this company: the "rotational programmes" and the "mobility/diversity". The first provides for the recruitment of young foreign talents who usually spend a few years in the local plant and who, later, leave for new destinations in the same or in a new company. The second provides the presence in the local plant, not even necessarily for a long period, of foreign established managers, in order to favour cultural "contamination" and to create, in this way, added value for the company. To this "resident" and "semi-resident" component, another transitory and temporary group must be added, consisting in those technicians, businessmen and managers who frequently move from one place to another, passing through the Sangro Valley.

The case of the Japanese community follows on from the story that initiated at the end of the Seventies. The group is composed of 39 individuals who are all managers in the Honda factory and their family members. Thirty-five of these individuals reside in the largest and most populated municipality of the area, with the best services, 20 minutes from the firm by car. Generally, these people arrive directly from Japan, spend an average period of 3-4 years in the area and then return or move to another Honda firm.

\section{Conclusion}

The migratory model of the area is linked to two main factors:

- the local economy: the presence of job opportunities both for non-specialized manpower and for managers and entrepreneurs;

- the local community: the incentive policies put into effect by some municipalities and the capacity for hospitality that characterizes some mountain communities.

The first factor is particularly important in attracting citizens from developed countries (such as Japan). The second is particularly relevant in the reception of citizens from developing countries (such as Albania, Yugoslavia, Morocco) who, upon their arrival on the Adriatic coasts, find a "refuge" in this valley.

51 A productive track for new investigations could be international temporary mobility, both of the local people who move abroad and of the foreigners who move to the Sangro Valley. It could be useful to complete the picture of an area which combines, in such a small territory, very diverse migratory paths due to very different objective factors and subjective motivations.

It represents precisely one of those "local characters" which represent Italy. 


\section{BIBLIOGRAPHY}

AAVV (2001), Storia dell'emigrazione italiana. Partenze, Roma, Donzelli.

AAVV (2002), Storia dell'emigrazione italiana. Arrivi, Roma, Donzelli.

BALDI S. \& CAGIANO DE AZEVEDO R. (1999), La popolazione italiana. Storia demografica dal dopoguerra ad oggi, Bologna, il Mulino.

BARBAGALLO F. \& BRUNO G. (1997), "Espansione e deriva del Mezzogiorno”, in AAVV, Storia dell'Italia Repubblicana. L'Italia nella crisi mondiale. L'ultimo ventennio. Vol. $3^{* *}$, Torino, Einaudi, pp. 401-470.

BECATTINI G. (1995-96), “I sistemi locali nello sviluppo economico italiano e nella sua interpretazione", Sviluppo Locale, II-III, 2-3, pp. 5-25.

BODO G. \& VIESTI G. (1997), La grande svolta. Il Mezzogiorno nell'Italia degli anni novanta, Roma, Donzelli.

CARBONI C. (1996), "Delimitazione e progettazione dei distretti industriali in Abruzzo", BURA, Anno XXVII, n. 39.

CARITAS (various years) Immigrazione. Dossier Statistico, Roma, Anterem.

CERSOSIMO D. \& DONZELLI C. (2000), Mezzo Giorno. Realtà, rappresentazioni e tendenze del cambiamento meridionale, Roma, Donzelli.

CLEMENTINO A. (1995), "Il processo di sviluppo industriale nella Valle del Sangro", in ORIOLI S. (a cura di), La città del Sangro. Economia, Territorio, Ambiente ed Enti locali in Val di Sangro, Bomba, Troilo Editore.

CRESA (2001), Annuario delle Industrie Abruzzesi, L'Aquila, CRESA.

DE ROSA L. (1997), Lo sviluppo economico dell'Italia dal dopoguerra a oggi, Bari, Laterza.

FABBRIS L. (1989), L'indagine campionaria. Metodi, disegni e tecniche di campionamento, Roma, NIS.

GINSBORG P. (1990), A history of contemporary Italy. Society and Politics 1943-1980, London, Penguin Books.

ISARD W. (1960), Methods of Regional Science. An Introduction to Regional Science, New York, The Technology Press of M.I.T.

ISTAT (various years, a), Censimento Generale dell'Industria e dei Servizi, Roma, Istat.

ISTAT (various years, b), Censimento Generale della Popolazione e delle Abitazioni, Roma, Istat.

ISTAT (various years, c), Movimento migratorio della popolazione residente. Iscrizioni e cancellazioni anagrafiche, Roma, Istat.

ISTAT (various years, d), Cittadini Stranieri, Roma, Istat.

MONTANARI A. (2005), “Human mobility, global change and local development”, Belgeo, 1-2, pp. 7-18.

MONTANARI A. \& CORTESE A. (1993), “Third World immigrants in Italy”, in KING R. (ed.), Mass Migrations in Europe. The Legacy and the Future, London, Belhaven Press, pp. 275-292. 
MONTANARI A. \& STANISCIA B. (2003), “Changing patterns and new migration trends in Italy”, in ISHIKAWA Y. \& MONTANARI A., (eds.), The new Geography of Human Mobility. Inequality Trends?, Rome, IGU - Home of Geography Publication Series, Vol. IV, pp. 141-167.

R\&P (RICERCHE E PROGETTI) (1981), La Fiat nel Mezzogiorno. L'esperienza degli stabilimenti automobilistici, Torino, Fiat.

SONNINO E. (1995), “La popolazione italiana: dall'espansione al contenimento”, in AAVV, Storia dell'Italia Repubblicana. La trasformazione dell'Italia: sviluppo e squilibri. Vol. 2*, Torino, Einaudi, pp. 531-585.

STANISCIA B. (2002), “I Patti Territoriali per l'Occupazione nell'Unione Europea”, Sviluppo Locale, IX, 19, pp. 8-42.

STANISCIA B. (2003), L'Europa dello sviluppo locale. I Patti territoriali per l'occupazione in una prospettiva comparata, Roma, Donzelli.

SVIMEZ (various years), Rapporto sull'economia del Mezzogiorno, Bologna, il Mulino.

TRIGILIA C. (1992), Sviluppo senza autonomia, Bologna, il Mulino.

\section{NOTES}

1. 49 municipalities, $1270 \mathrm{~km}^{2}$ of surface, $549 \mathrm{~m}$ average altitude, a population of 126,881 inhabitants.

2. In this paragraph no reference will be made to the development path that characterised Southern Italy, as a whole, in the period taken into consideration. A very established and sedimented literature already exists on the issue and a debate on this point is beyond the purposes of the present study. Very interesting theses about the development of the Mezzogiorno are proposed by Ginsborg (1990), Trigilia (1992), Barbagallo and Bruno (1997), Bodo and Viesti (1997), De Rosa (1997), Cersosimo and Donzelli (2000).

3. With regard to economic development, the data taken into consideration are those of the Censuses of 1961-1971-1981-1991-2001, at the municipal level.

4. As far as human mobility is concerned, the data used come from several sources.

For the period 1961-1981, at municipal level, official data on foreign presence are not available in Italy. The existing data concern entry and exit movements, registry inscriptions and cancellations for motives of transfer of residence to/from a municipality from/to abroad. However, these movements do not indicate neither the country of provenance of the subjects nor their nationality. Therefore, this data are useful to verify human exchanges in the area of study with the rest of the world, i.e. the foreign migratory balance, evaluated on a quantitative basis. Furthermore, the data do not measure the qualitative aspect. In order to fill this gap, a subjective method has been used here: the "Testimoni Privilegiati" ("Key-persons") (Fabbris, 1989). In particular, the "Testimoni Antropologico Culturali" ("Anthropological-Cultural key persons") have been used. These are subjects who, due to their personal and professional history, have been involved in the vicissitudes of a small territory, such as a municipality. They are mayors, public employees, medical doctors, teachers, all those who, because of their roles in local society, have had direct access to the "contingent", or to the "transient" and who, because of their professional and personal capacity, have preserved the memory of those events. They can, therefore, subjectively compensate for the lack of objective data. Five individuals have been interviewed who, at the time of the events referred to, were the following: two mayors of municipalities, a registry employee, a trade union representative and a manager in a multinational company. 
For the period 1981-1991, the Population Census data were used. The data from 1981 register foreign residents at a municipal level and their profession. The 1991 data register, at a municipal level, foreign residents based on the macro-area of provenance. These data were analysed and thereafter commented upon by the "Testimoni Antropologico Culturali" cited above.

For the last decade, the Nineties, the 2001 Census data will be soon available. At the present moment, these data have not yet been published by ISTAT (National Institute of Statistics). In order to compensate for this missing information, data from the municipal registries have been used, the most up-to-date referring to $31 / 12 / 2000$. These data are obviously not automatically comparable with those corresponding to the previous decade, having been obtained from a different source. However, referring to the same phenomenon - foreign residents in the municipalities of the area - where the strong element is precisely that of residence, indicating a certain stability within time, certain qualitative, diachronic considerations are possible. This analysis has been supplemented with qualitative information provided by the present mayors and registry employees of the main municipalities of the area.

5. In this paragraph the theme of the migratory path that characterised Southern Italy, as a whole, in the period taken into consideration, will not be treated. For a reconstruction of that path, interesting theses are contained in Montanari and Cortese (1993), Sonnino (1995), Baldi and Cagiano de Azevedo (1999), AAVV (2001), AAVV (2002), Montanari and Staniscia (2003), Caritas (various years), SVIMEZ (various years).

\section{ABSTRACTS}

The Sangro Valley, the economy of which was characterised mostly by the agricultural sector until the beginning of the 1970s, experienced an industrial development from the end of that decade. It was, an "exogenous development", with a relevant presence of external enterprises within which the level of internationalisation was very high. Industrial development and the process of productive internationalisation were followed by an intense internal migratory flow and a less intense international migratory flow. The international migratory flow can be divided into two main components: (i) a large group of unskilled manpower, composed of unspecialised manual workers, usually young; (ii) a small group of highly-skilled international employees, managers and engineers.

The aim of this study is to investigate the phenomenon of international migratory flows, to underline a positive correlation between the mobility of financial capital and the mobility of human capital.

La Vallée du Sangro, qui était caractérisée par une économie fondée, en prévalence, sur l'agriculture jusqu'au début des années 1970, a connu un développement industriel à partir de la fin de la décennie. Il s'agissait d'un développement exogène, caractérisé par une présence importante d'entreprises extérieures qui présentaient un très haut niveau d'internationalisation. Le développement industriel et le processus d'internationalisation de la production furent suivis par un très intense flux migratoire intérieur et par un moins intense flux migratoire international. Le flux migratoire international peut être réparti en deux éléments principaux: (i) une nombreuse main-d'oeuvre non spécialisée, composée par des ouvriers jeunes ; (ii) un petit groupe d'employés internationaux très spécialisés, composé de cadre-supérieurs et d'ingénieurs. L'objet de cette étude est l'investigation du phénomène des flux migratoires internationaux, dans 
le but de mettre en évidence une corrélation positive entre la mobilité des capitaux financiers et la mobilité des capitaux humains.

INDEX

Mots-clés: Abruzzes, Mezzogiorno, migrations internationales, développement

Keywords: Abruzzo, Mezzogiorno, international migration, development

\section{AUTHOR}

\section{BARBARA STANISCIA}

Dipartimento di Economia e Storia del Territorio, Università degli Studi “G. d'Annunzio", barbara.staniscia@tiscali.it 